\title{
The Impact of Differentiated Instruction on Students' Performance in Critical Reading
}

\author{
Sahril', Aulianti SN ${ }^{2}$, Muh. Safar Nur ${ }^{3}$ \\ Universitas Negeri Makassar, ${ }^{1,2,3}$ \\ Email: sahrilfbsunm@unm.ac.id
}

Submitted: 04/01/2021

Revised: 25/01/2021

Accepted: 10/02/2021

E-ISSN : $2579-4574$

P-ISSN : 2549-7359

\begin{abstract}
This research shows the importance of reading in various settings in critical reading learning. This research involves a study to improve two classes' experience and two students of Universitas Negeri Makassar in their critical reading class about their reading level during one semester by implementing a differentiated instruction model. The results showed a positive effect that differentiated instruction in critical reading learning on students' reading interest and reading level. Differentiated Instruction learning model by chances for students having an in-depth view of the target language, learning to look at their abilities in new ways, increasing their self-confidence, and using English to communicate and achieve authentic communication as an EFL learning goal. It is assumed that most participants see the Differentiated Instruction learning model as an effective means of facilitating communication and understanding in Critical Reading lecture.
\end{abstract}

Keywords: Critical Reading, Differentiated Instruction Model

https://ojs.unm.ac.id/eralingua

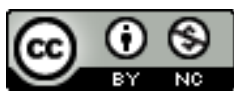

This work is licensed under a Creative Commons Attribution-NonCommercial 4.0 International License 


\section{INTRODUCTION}

One could contend that a steady test for instructors is to furnish understudies with the most ideal educating. It is sensible to accept that most instructors feel that their schooling can be improved somewhat. Nonetheless, it is almost inconceivable for instructors to adjust their education to suit every understudy's capacities and inclinations in the study hall (Lightbown \& Spada, 2013; Tomlinson, 2017). Homerooms are loaded up with various students who contrast socially and etymologically and in their psychological capacities, foundation information, and learning propensities. Grounds the nation over are tested with such variety. To upgrade understudy learning and expand their accomplishment, numerous grounds utilize various directions. Bohannan (2016) characterizes Differentiated Instruction as A cycle of educating and learning approaches for understudies with differing capacities in a similar class. The point is to enhance every understudy's turn of events and individual accomplishment by arriving at every understudy where the person in question is Instead of approaching understudies to change the educational program for themselves. Expanding a reasonable comprehension of the material being instructed is the objective of each teacher. With the current variety in the homeroom, it is practically unthinkable for speakers to challenge every one of their understudies in a similar class except if they change the educational program by arriving at all understudies. Singular understudy contrasts are a significant factor why this is a particularly unmanageable undertaking. Lightbown and Spada (2013) underscore an instructing approach that is Simply clinging to one technique for teaching all understudies, accepting that understudies acquire a similar encounter and would at last confine understudies' learning and development openings. In this manner, by acknowledging understudy contrasts, instructors can be more qualified to adjust and separate their education to understudies however much as could reasonably be expected (Heacox, 2012). Requests to address understudy variety in homerooms today appear to be inescapable (Subban, 2006; Tomlinson et al., 2003). An ever-increasing number of understudies reflect various foundations and contrasts in, for instance, learning styles, inspirations, capacities, needs, and interests. This variety of understudies difficulties grounds execution. This requires a fitting educating approach. Grounds and teachers are liable for adjusting to the diverse formative requirements and individual students' levels (Tomlinson et al., 2003). A one-size-fits-all instructing approach depends on the presumption that everything understudies can be dealt with a similar way. It disregards the different necessities of understudies (Fox \& Hoffman, 2011; Subban, 2006).

Interestingly, the Differentiated Instruction (DI) approach is required to think about contrasts between understudies, recognize their qualities, and oblige their impediments (Heacox, 2012; Subban, 2006; Tomlinson et al., 2003). Meeting understudy contrasts is a test because these distinctions can be ascribed to different understudy attributes, for example, student interests, learning styles, level of advancement, learning speed, capacities, social foundation, language level, perspectives, administrative methodology, and so on (Ledgerwood et al., 2018). Similarly, there are numerous varieties in DI execution; for instance, instructors place various students in various gatherings (as indicated by their degree of premium), present an alternate arrangement of activities, offer more help and input 
to perusers who troubles, gives enhancement material to savvy understudies, puts pretty much severe requests on the accomplishment of learning targets, apportions less time, offers greater consolation to explicit understudies, permits understudies to work alone instead of in gathering settings, picks beginning stages to encounter learning cycle (Heacox, 2012; Mavidou \& Kakana, 2019; Waterman, 2014). These models show how DI can impact choices that speakers make, learning destinations, learning content, educational systems, media use, assessment draws near, and hierarchical factors (gathering, timing, and so on)

\section{LITERATURE REVIEW}

As per Hymn Tomlinson (2001), Differentiated Instruction is "the cycle understudies use to learn, the item or exhibition of their learning, the climate where they learn, or the substance they learn." Brought about by the expanded educational plans, understudies' quantity needs extra help with disguised agreement and guidance. Numerous regions have consolidated supporting these understudies through a layered showing model called Differentiated Instruction (DI). DI is a way to deal with assistance understudies who are in danger of encountering learning troubles. DI depends on re-confirming the People with Incapacities Act (Thought) to give the learning support until enduring misfortune they need (Bursuck and Spaces, 2010). This technique is a layered program that furnishes understudies in various conditions with instructional help, planning to improve understudy scholastic accomplishment (Jones, Yssel and Award, 2012). One substance in which the DI show has been gotten to supply individual and essential guidance is examining. Albarran \& Sandbank (2019) state that "the current instructive approach atmosphere underlines the need to bring 'proof-based advancement's to instructive practice as a rule and critical reading guidance specifically." This implies that while DI may have an incentive in all understudy territories, it very well may be extraordinary for understanding guidance.

Jones (2012) talks about the possibility that DI models, in the feeling of critical reading, are utilized to consolidate proof-based mediations to assist understudies with building up their critical reading abilities to perceive understanding challenges and keep understudies from falling flat. Because of their turn of events, giving a layered educational program worldview to oblige students' necessities is like separated learning. Both are intended to help the requirements of kids dependent on their singularity. This subject will fill in as a top to bottom glance at different approaches to give the instructional framework diverse fruitful guidance by following the DI model. This paper would provide perusers with a comprehension of the reaction model to intercession and why instructors need to remember essential attributes for the three phases of reaction to mediation. To begin with, I will give an outline of what the model for DI is. Additionally, students will be offered an overview of the estimation of qualification in top-notch mediation programs, enhanced by different methods that can be utilized to give best practices to understudies all through the program. At that point, I will furnish perusers with a review of how the DI model is generally utilized in proficiency conditions and how different strategies for individualizing learning for all understudies who require additional Differentiated Instruction could include second-level mediations. 


\section{RESEARCH METHOD}

This research is qualitative. Marshall \& Rossman (2014) define qualitative research as a broad approach to studying social phenomena. The various genres are naturalistic, interpretive, and increasingly critical, and they usually employ a variety of inquiry methods. Besides, Creswell \& Poth (2016) state that qualitative research investigates an understanding that explores social or human problems. Participants in this study were two classes of students of English Literature at Makassar State University. Students take the Critical Reading course as their basic knowledge of English-speaking countries' culture (West).

Via work samples and interviews, the data for this analysis was gathered. Students conducted two reading tests in this sample to demonstrate their achievements and deficiencies in their commitment, fluency, awareness and reading level. Two reading interest surveys were also conducted, which examined their responses to establish a correlation between reading rate growth and reading interest. Interviews were performed to investigate methods and assistance given for the reactions of students to specific instruction. For their similarity and successful ways, the responses given by the researcher were checked and evaluated.

\section{RESULTS AND DISCUSSION}

Tests of work and meetings got the information. Understudies in this investigation, directed two tests to show their qualities and inadequacies regarding their responsibility, familiarity, and mindfulness, just as their degree of critical reading. Two critical reading revenue studies were additionally led that inspected their reactions to build up a connection between critical reading rate development and understanding revenue. In the second phase of the mediation model reaction, interviews were performed to address understudies' intercessions and assets. For their closeness and effective strategies, the specialist's reactions were checked and assessed. For the two classes, the accompanying table presents the revealed assessment results. This is being regulated in March 2020.

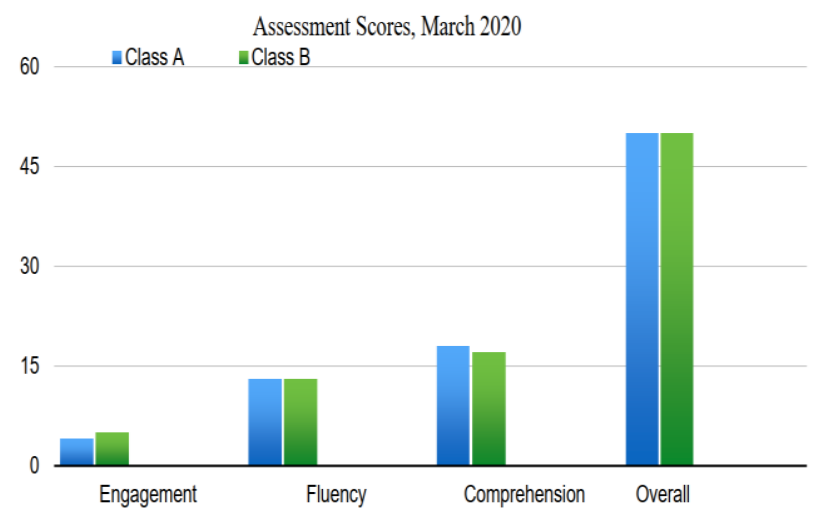

Figure 1. Assessment Scores, March 2020

The table underneath clarifies the information recorded when understudies took the last evaluation in June 2020. This appraisal is utilized to quantify the development embraced by understudies. 


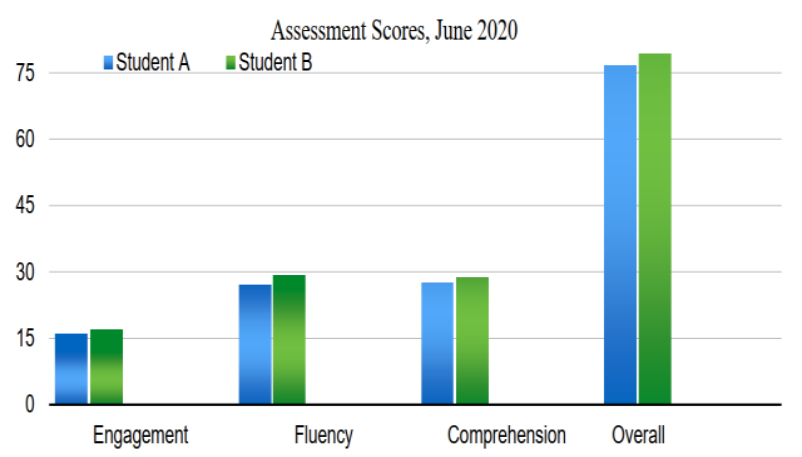

Figure 2. Assessment Scores, June 2020

In March, class A was given a level 50 adaptation utilizing anecdotal content when the primary critical reading assessment was doled out. They scored four out of eight potential purposes of cooperation in critical reading, fourteen out of seventeen on familiarity with critical reading, and seventeen out of twenty five on the impression of critical reading. As per the reviewing outline, this puts class An at the 50 fiction standard of autonomous critical reading. This is around one semester beneath the benchmark. In June, a level 60 assessment utilizing faithful to life text was given to class $A$. He scored five out of seven potential purposes of connection in reading, fifteen out of seventeen on familiarity with reading, and 21 out of 24 on understanding discernment. This puts class $A$ at a genuine free reading standard of 60 , as per the reviewing guide. At level 50, utilizing invented records, the principal critical reading assessment offered to class B. She scored four out of seven focuses on understanding investment, twelve out of fifteen on understanding familiarity, and eighteen out of twenty four on understanding arrangement. The positions of Class B on the 50 fictions understanding imprint, around one level underneath adequate. For student $B$, the June critical reading test offered different results. She was reviewed genuine content at level 60 for this assessment. On understanding investment, she scored six out of eight evaluations, twelve out of seventeen on understanding familiarity, and twenty out of twenty four on an understanding agreement. The development put Class B at an autonomous true to life critical reading normal of 60 .

The assessments obtained during the examination uncovered that each of the five members experienced advancement in their understanding guidelines during their second-semester grounds. For understudies, however, the level of progress changes. In contrast, the fifth member kept the critical reading level yet fortified their capacity to peruse and decipher text fluidly. Numerous factors permitted this result to happen. The two students members offered intellectual critical reading intercession assets, as recently noted. The two understudies additionally directed a critical reading interest overview to clarify the association that could be drawn between the ability of an understudy to partake in writing and the accomplishment of an understudy's critical reading. The survey of information found that the one understudies who got instructional mediation benefits all expanded significantly. While another understudies who completed the subsequent semester critical reading at the necessary speed arrived at the region's subsequent semester understanding objectives, each of the three understudies exhibited progress from the Walk critical reading assessment to the June critical reading assessment in expanding one understanding semester. It may very well be surmised 
that consistently, another critical reading intercession administration prompts the development of students' critical reading.

Understudy student $A$ during the meeting, Critical reading Analyst 2 communicated that understudy $A$ needed more opportunity to zero in on the content, read it out loud in an agreeable climate, and investigate the content to help him in building perception. Critical reading Scientist 2 made an errand to do this that was just offered to Understudy. She needed to get messages at the easy one, for example, youngsters' writing, to peruse so anyone might hear and address her more youthful sibling at home with her. This gives a connection among life and education for Understudy An and offers expanded insight of understanding familiarity and enthusiasm for critical reading.

This ability is meant the school, where I saw him and his friends assemble networks of books, where they can peruse a similar book and discussion it as they read. This causes Understudy $A$ to get more inspired by and with his friends in writing. Understudy An's inclination study of June critical reading shows that he appreciates critical reading. He composed that he peruses for no particular reason outside of class and is engaged when he peruses. He additionally noticed that he felt "certain" critical reading out loud, and he expressed "yes" when inquired as to whether he preferred the errand. "I am critical reading to my sibling." Understudy A completed his second semester because of the unique methodologies advertised. At the semester stage, he was critical reading. Understudy B: Analyst 1 clarified in his meeting that, with Understudy $B$, he utilized a method who focused on his requirements. For Understudy $B$ is including assisting him with finding the title at his level and getting an outstanding possibility with Scientist Critical reading 1 to peruse this story and investigate his content understanding. He frequently got some information about the key ideas and conversations he was critical reading to make these capacities familiar. He, step by step, advanced to have the option to contemplate a book and autonomously expound on it. This is clear in our group too. Understudy B keeps on communicating his considerations about the content to be perused to his companions in little gathering conditions and the local area all in all gathering occasions as the semester advances. He said that he appreciates critical reading and generally wants to peruse outside of grounds in his June critical reading interest survey. He additionally composed that he had distributed four books as of late. As her lecturer, I found that she started to feel more loosened up having risks in her study hall, which was reflected in her degree of enthusiasm and eagerness for her cohorts to trade thoughts. The critical reading level of Understudy B improved drastically because of the procedures and assets gave in semesters one and two of the DI model.

Understudy A: Critical reading Analyst 1 and I both found that Understudy A was consistently eager to complete his work with peers who read at a more significant level than him. Accordingly, to build up a profound perception, he didn't do his hardest and read the content without any problem. To help Understudy $B$ in this regard, he was asked by Specialist Critical reading 1 to peruse a portion of the lower-level messages, so anyone might hear. Critical reading Scientist 1 communicated during his meeting that this occasionally disturbed Understudy A, however it was a productive route for him to practice familiarity with critical reading, perceive the vital idea of the new content, and make inferences to address inquiries outside the content. He additionally requested that Understudy B keep in 
touch with different understudies locally about the subject of the story he was critical reading and offer his considerations. He found that Understudy A's paper didn't give as much composed and exhaustive confirmation as his oral answers. To his companions in the gathering. He composed that his critical reading disposition depended on the content in Understudy A's semester-end critical reading interest overview. He likewise noticed that he doesn't peruse outside of class routinely, however, that he as of late found a book he prefers. He composed that he wanted to peruse out loud. I expect that he didn't expand his critical reading level to the necessary semester level benchmarks, in view of Understudy A's reluctant activities to partake in writing.

Nonetheless, the individual work he gave to Scientist 1 caused him to increment the norm of critical reading by one level. Understudy B's: Since Understudy B was put on the Understudy rundown to be firmly viewed because of his score in the past semester, during the grounds semester, I separated the direction I gave to Understudy B in our courses. I offer visuals like montages of stories to Understudy B to perceive significant data in the content and sort out these subtleties all together. When tending to inquiries concerning the content being perused, Understudy B ought to allude back to the graph coordinator. Understudy B steadily disguised this ability, and he turned into a more free peruser and analyst. Understudy $B$ also visits little local meetings and joint meetings to audit the books he's perused. I asked understanding inquiries at this meeting to assist him track his translation of what he was critical reading and to urge him to pose inquiries about his books and think equitably about the writings.

The critical reading inclination review by Understudy $B$ uncovered blended sentiments about writing. She expresses that she barely peruses outside of class without being approached to do as such, however, when she peruses, she feels inquisitive, which directs her to understand more. When he read, Understudy B's advantage helped him produce a more profound association with writing, which added to the development he accomplished during the semester nearby. Thus, he completed the process of critical reading at semester level for the subsequent semester. Because of this examination, it tends to be gathered that it urges understudies to improve their critical reading aptitudes by offering separated understanding guidance. Albeit just three understudies in the examination got to scholarly mediation assets, these five understudies got discrete training in either semester one, semester two, or both during their second semester of grounds semester. In the little gathering climate, additionally alluded to as level two of the DI model, the three understudies who endorsed the critical reading scientist had various prospects. In level one, their English quality class, they likewise go through the different arrangement. Albeit second-level administrations were not offered to two understudies who didn't get study administrations, they were given separated direction at level one. This is accomplished by providing all understudies with standard audits, which is fundamental as per Brimijoin (2005), to follow their critical reading understanding of the content that is being perused in class. I work together with them independently to break down the writing and give them appreciation methods and visual game plans that assist them with learning and outperform the content when they exhibit a lacking translation of the semester-level content. On the off chance that I do this examination once more, I will furnish Understudy $A$ and Understudy B with more opportunities to peruse writing that coordinates their 
inclinations. Morgan (2014) noticed that qualification requires changing instructional chances in educating and testing to suit understudy learning styles. Understudy A and Understudy B demonstrated that they can communicate with writing and work at a more prominent degree to decipher the content. Simultaneously, their interest is remembered for the understanding cycle.

I expect to be that if I had assisted these understudies with getting the perusers they were keen on right off the bat in the grounds semester, they would have encountered more advancement than they did I will likewise email Researcher1 and Researcher 2 toward the start of the semester to guarantee that I furnish my understudies with the most effective approaches to acquire their input on how best to address the requirements of Understudy B and Understudy A, since they don't get second-degree preparing, yet will profit by it. In the event that I do this, I feel that I will have the option to give these two understudies more opportunities to acquire singular guidelines for critical reading, which will empower them to gain more ground.

\section{CONCLUSION}

Differentiated Instruction is a beneficial methods for conveying viable and customized exercises for understudies. Examination exhibits that while instructing is adjusted to understudies' abilities and necessities, they are bound to succeed (Morgan, 2014). Understudies seem to flourish paying little mind to how much they get training as differential learning is joined in the Answer for the Mediation Model. This exploration uncovers that when understudies are offered different showing encounters, critical reading rates start to improve. The discoveries additionally propose that they are bound to create when an understudy puts resources into critical reading and has an individual and passionate connection with it.

\section{REFERENCES}

Albarran, S. A., \& Sandbank, M. P. (2019). Teaching non-target information to children with disabilities: An examination of instructive feedback literature. Journal of Behavioral Education, 28(1), 107-140.

Bohannan, J. B. (2016). Differentiated Instruction: Inclusive Strategies for Secondary Science.

Brimijoin, K. (2005) Differentiation and high states testing: An oxymoron? Theory Into Practice, 44(3), 254-26. doi.org.pluma.sjfc.edu/10.1207/s15430421tip4403_10

Bursuck, B. \& Blanks, B. (2010). Evidence-based early reading practices within a response to intervention system. Psychology in the Campuss, 47(5), 421-431. DOI:10.1002/pits.20480

Creswell, J. W., \& Poth, C. N. (2016). Qualitative inquiry and research design: Choosing among five approaches. Sage publications.

Fox, J., \& Hoffman, W. (2011). The differentiated instruction book of lists (Vol. 6). John Wiley \& Sons.

Heacox, D. (2012). Differentiating instruction in the regular classroom: How to reach and teach all learners (Updated anniversary edition). Free Spirit Publishing.

Jones, R. E., Yssel, N. \& Grant, C. (2012). Reading instruction in tier 1: Bridging the gaps by nesting evidence-based interventions within differentiated 
instruction. Psychology in the Campuss, 49(3), 210-218. DOI: 10.1002/pits.21591

Ledgerwood, A., Eastwick, P. W., \& Smith, L. K. (2018). Toward an integrative framework for studying human evaluation: Attitudes toward objects and attributes. Personality and Social Psychology Review, 22(4), 378-398.

Lightbown, P. M., \& Spada, N. (2013). How languages are learned 4th edition-Oxford Handbooks for Language Teachers. Oxford university press.

Marshall, C., \& Rossman, G. B. (2014). Designing qualitative research. Sage publications.

Mavidou, A., \& Kakana, D. (2019). Teachers' Experiences of a Professional Development Program for Differentiated Instruction. Creative Education, 10(3), 555-569.

Morgan, H. (2014). Maximizing student success with differentiated learning. The Clearing House: A Journal of Educational Strategies, Issues and Ideas, 87(1), 34-38. doi:10.1080/00098655.2013.832130

Spencer-Waterman, S. (2014). Handbook on differentiated instruction for middle \& high schools. Routledge.

Subban, P. (2006). Differentiated instruction: A research basis. International Education Journal, 7(7), 935-947.

Tomlinson, C. A. (2001). Differentiated Instruction in the Regular Classroom: What Does It Mean? How Does It Look?. Understanding Our Gifted, 14(1), 3-6.

Tomlinson, C. A. (2017). How to differentiate instruction in academically diverse classrooms. ASCD.

Tomlinson, C. A., Brighton, C., Hertberg, H., Callahan, C. M., Moon, T. R., Brimijoin, K., Conover, L. A., \& Reynolds, T. (2003). Differentiating instruction in response to student readiness, interest, and learning profile in academically diverse classrooms: A review of literature. Journal for the Education of the Gifted, 27(2-3), 119-145. 